\title{
Časová rezidua odečtů $P$ vln ze severokorejské jaderné exploze $z$ roku 2017 a jejich příspěvek $k$ problematice nehomogenit litosféry ve střední Evropě
}

\author{
P-wave arrival time residuals from the 2017 North Korean nuclear test and its contribution \\ to the problems of lithospheric inhomogeneities in the Central Europe
}

\author{
Josef Havír̆ $\rightarrow$ \\ Ústav fyziky Země, PřF MU, Tvrdého 12, 60200 Brno
}

\section{Key words:}

seismic monitoring, nuclear explosion, time residuals, lithospheric inhomogeneities

\section{$\square$ havir@ipe.muni.cz}

Editor:

David Buriánek

\begin{abstract}
Lateral inhomogeneities of the Earth's interior (crust and mantle) have significant influence on the arrival time of seismic signal detected by station in framework of seismic monitoring. Observed arrival times differ from values presumed on the basis of a homogeneous global velocity model, these differences are quantified by the arrival time residuals $T_{r}$. In this article, the effect of lateral inhomogeneities in Central Europe on detected $P$ wave arrival times is demonstrated using seismic signal of the North Korean nuclear test (2017). Magnitude mb of this explosion exceeded value 6 and this seismic event is extraordinarily appropriate for study of time residuals for its sharp beginning and high amplitude of its $P$ wave signal. The arrival times are picked with high accuracy (less than $0.2 \mathrm{~s}$ ) even in teleseismic epicentral distances, consequently the obtained time residuals more reliably reflect effects of velocity inhomogeneities in comparison to other seismic events. For the study of arrival time residuals in Central Europe, waveforms recorded by several hundreds of seismic stations were evaluated. Final picture of the time residuals distribution shows several regions with anomalous values of $T_{r}$, the western and northern regions of the Western Carpathians, the Pannonian Basin and the Eastern Alps are briefly discussed with regard to their possible origins. Given seismic monitoring in Central Europe (above all on the territory of the Czech Republic), significantly anomalous $P$ wave arrival time residuals (exceeding value of 1 second) in the western part of the Western Carpathians are very important.
\end{abstract}

Doporučená citace článku: Havír, J. (2019). Časová rezidua odečtů P vin ze severokorejské jaderné exploze z roku 2017 a jejich príspěvek $k$ problematice nehomogenit litosféry ve střední Evropè. - Geologické výzkumy na Moravě a ve Slezsku, 26, 1-2, 103-108.

DOI: https://doi.org/10.5817/ GVMS2019-1-2-103
Úvod

V posledních desetiletích byla provedena celá řada studií rychlostních nehomogenit v evropské (respektive středoevropské) litosféře na základě refrakčních profilů (zejména v rámci projektů TRANSALP, CELEBRATION 2000, ALP 2002 a SUDETES 2003, viz Brückl et al. 2007; Cassinis 2006; Grad et al. 2008, 2009; Hrubcová et al. 2008, 2010; Janik et al. 2011, a na ně navazujícího 3D rychlostního modelování, viz např. Behm et al. 2007; Behm 2009) a analýzy seismogramů zemětřesení (např. Karousová 2013; Koulakov et al. 2009; Legendre et al. 2012). Tyto práce přinesly spoustu nových zajímavých poznatků o variabilitě stavby kůry a svrchního pláště, ale současně také ukázaly, jak mnoho toho ještě o hlubších partiích horninového prostředí v našem regionu nevíme. Přitom projevy nehomogenit horninového prostředí mají v některých geovědních oborech významné praktické důsledky. K nim patří také problematika časů seismických vln odečtených na seismických stanicích, která je v rámci tohoto článku demonstrována na příkladu zpracování signálu severokorejské jaderné exploze ze září 2017. 
Jaderná exploze provedená dne 3.9. 2017 na jaderné střelnici Punggye-ri v sv. části KLDR byla šestou a nejsilnější severokorejskou jadernou explozí uskutečněnou na této lokalitě. Hodnoty magnituda mb odvozeného z objemových vln, které byly vypočítány nezávisle na sobě Ústavem fyziky Země Masarykovy univerzity v Brně (ÚFZ), v Mezinárodním datovém centru CTBTO (IDC) a v centru národní seismologické služby USA (NEIC), se pohybují mezi hodnotami 6,1 a 6,4 (tab. 1). Seismický signál generovaný touto pokusnou jadernou explozí byl ve výjimečně dobré kvalitě registrován velkým počtem stanic po celém světě, včetně stanic provozovaných ÚFZ v Brně. Ostrý začátek a velká amplituda první výchylky signálu $\mathrm{P}$ vlny umožňují na řadě stanic odečítat časy detekce podélné vlny i v teleseismických vzdálenostech s chybou menší než 0,2 sekundy.

Rozdíly skutečně zjištěných a teoreticky předpokládaných časů detekce $\mathrm{P}$ vlny (tzv. časová rezidua $\mathrm{T}_{\mathrm{r}}$, viz obr. 1) na stanicích situovaných v regionu střední Evropy tak v diskutovaném př́ípadě výjimečně ostře odráží vliv nehomogenit $\mathrm{v}$ horninovém prostředí, a to nejen $\mathrm{v}$ korových, ale i $\mathrm{v}$ pláštových partiích Země. Je třeba vzít v úvahu, že výsledné časové reziduum $\mathrm{T}_{\mathrm{r}}$ je výsledkem více nehomogenit ovlivňujících seismický signál v různých hloubkách. $\mathrm{V}$ případě více vlivů se může jejich účinek zesilovat (časové reziduum se zvyšuje), nebo naopak vzájemně oslabovat (časové reziduum se snižuje). Výhodou je při interpretaci možných vlivů ten fakt, že seismický paprsek přicházející z teleseismické vzdálenosti je strmě ukloněný. $\mathrm{V}$ případě severokorejské jaderné exploze dosahují úklony seismických paprsků detekovaných na evropských seismických stanicích hodnot přibližně $80^{\circ}$ (úhel svíraný paprskem a rovinou zemského povrchu) a paprsky tedy prochází v různých úrovních litosféry horninovými tělesy, které jsou umístěny víceméně nad sebou (rozdíl vůči vertikálnímu paprsku je relativně malý).

Tab. 1: Tabulka lokací jaderného testu provedeného v sv. části KLDR v září 2017, lokace byly vypočítané nezávisle v ÚFZ v Brně (ÚFZ), v Mezinárodním datovém centru CTBTO (IDC) a v centru americké národní seismologické služby (NEIC), respektive byly zjištěny z povrchových deformací studovaných pomocí satelitních snímků (Wang - lokace převzata z práce Wang et al. 2018). Magnitudo mb je počítané $z$ objemových vln teleseismických fází.

Tab. 1: Location parameters of nuclear explosion conducted in NE part of the North Korea in September 2017, locations were independently determined at the Institute of Physics of the Earth (ÚFZ), at the International Data Centre CTBTO (IDC) and at the U.S. National Earthquake Information Centre (NEIC), or it was detected from surface displacement studied using satellite imagery respectively (Wang - location after Wang et al. 2018). Magnitude $\mathrm{mb}$ is calculated using teleseismic body waves.

\begin{tabular}{|l|c|c|c|c|c|}
\hline datum & $\begin{array}{c}\text { čas } \\
\text { vzniku }\end{array}$ & $\begin{array}{c}\text { zem. } \\
\text { šírka }\end{array}$ & $\begin{array}{c}\text { zem. } \\
\text { délka }\end{array}$ & $\begin{array}{c}\text { magnitudo } \\
\text { mb }\end{array}$ & zdroj \\
\hline \multicolumn{6}{|c|}{ jaderná exploze } \\
\hline 3. 9.2017 & $03: 30: 01,4$ & 41,304 & 129,046 & 6,4 & ÚFZ Brno \\
\hline 3.9 .2017 & $03: 30: 01,1$ & 41,321 & 129,035 & 6,1 & IDC \\
\hline 3.9 .2017 & $03: 30: 01,9$ & 41,343 & 129,036 & 6,3 & NEIC \\
\hline 3.9 .2017 & & 41,300 & 129,078 & & Wang \\
\hline
\end{tabular}

\section{Epicentrum jevu a předpokládané časy detekce}

Pro určení předpokládaných časů detekce $\mathrm{P}$ vln byla použita lokace vypočtená na ÚFZ v Brně (tab. 1) s využitím globálního rychlostního modelu IASP91 (Kennett 1991).

Epicentra exploze z roku 2017 se podle výsledků lokací seismických vln nachází v prostoru hory Mantap, ve vzdálenosti 4 až $8 \mathrm{~km}$ sz. až ssz. od objektů jaderné střelnice Pungyye-ri (obr. 2) pozorovatelných na satelitních

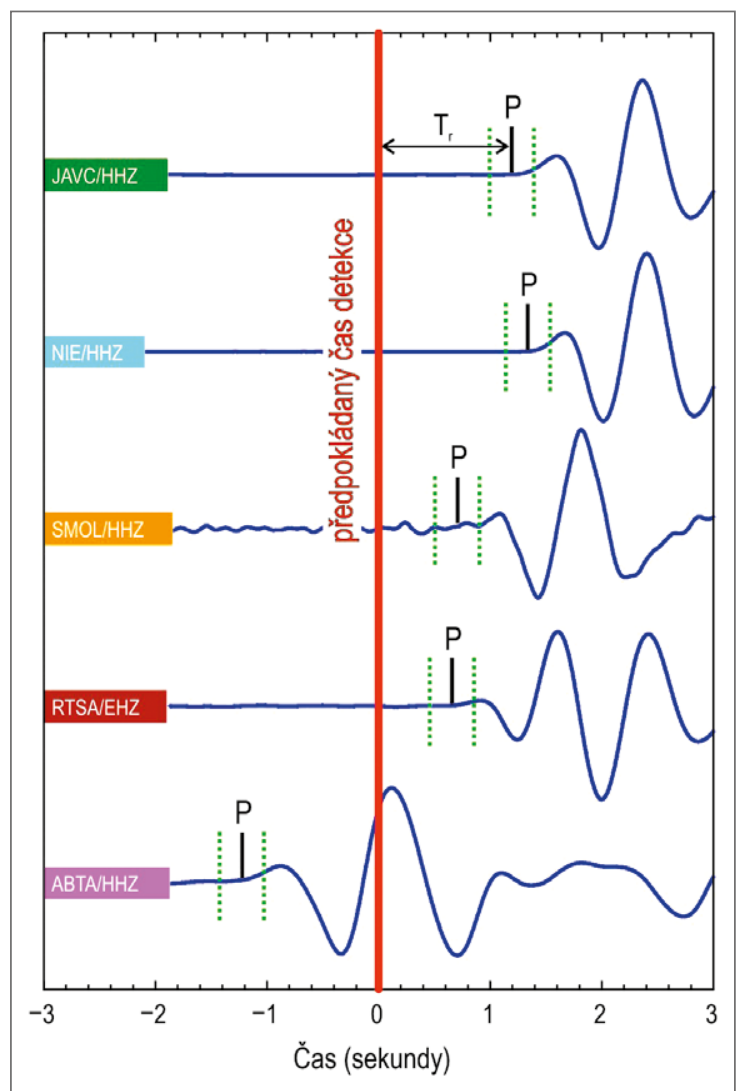

Obr. 1: Seismický signál severokorejské jaderné exploze ze dne 3. 9 . 2017 zaznamenaný na stanicích umístěných v prostoru střední Evropy (vertikální složka, signál je filtrován pásmovou propustí v rozmezí 0,6 až 5,0 Hz; signál složky HHZ je širokopásmový, zatímco složka EHZ je krátkoperiodická). Časová osa je relativní, posuny vzhledem k předpokládanému času detekce (červená linie) odpovídají časovým reziduím $\mathrm{T}_{\mathrm{r}}$ (tj. rozdílu mezi skutečným a předpokládaným časem detekce). Stanice: JAVC (Velká Javořina, Česká republika, $48,86^{\circ} 17,67^{\circ}, \mathrm{T}_{\mathrm{r}}=1,2$ ); NIE (Niedzica, Polsko, $49,42^{\circ} 20,30^{\circ}, \mathrm{T}_{\mathrm{r}}=1,3$ ); SMOL (Smolenice, Slovensko, $48,51^{\circ} 17,43^{\circ}, \mathrm{T}_{\mathrm{r}}=0,7$ ); RTSA (Bad Reichenhall, Německo, $47,77^{\circ} 12,84^{\circ}, \mathrm{T}_{\mathrm{r}}=0,7$ ); ABTA (Abfaltersbach, Rakousko, $46,75^{\circ} 12,51^{\circ}, \mathrm{T}_{\mathrm{r}}=-1,2$ ).

Fig. 1: Waveforms of the North Korean nuclear explosion recorded on 3. 9. 2017 by European stations (vertical component, filtered by band-pass filter from 0.6 to $5.0 \mathrm{~Hz}$; components $\mathrm{HHZ}$ are high broadband, while component EHZ is extremely short period). Relative time axis, shifts related to presumed arrival time (red line) correspond to time residuals $\mathrm{T}_{\mathrm{r}}$ (it means, difference between presumed and observed arrival times). Stations: JAVC (Velká Javořina, Czech Republic, $48.86^{\circ} 17.67^{\circ}, \mathrm{T}_{\mathrm{r}}=1,2$ ); NIE (Niedzica, Poland, $49.42^{\circ} 20.30^{\circ}, \mathrm{T}=1,3$ ); SMOL (Smolenice, Slovakia, $48.51^{\circ} 17.43^{\circ}, \mathrm{T}_{\mathrm{r}}=0,7$ ); RTSA (Bad Reichenhall, Germany, $47.77^{\circ} 12.84^{\circ}, \mathrm{T}_{\mathrm{r}}=0,7$ ); ABTA (Abfaltersbach, Austria, $\left.46.75^{\circ} 12.51^{\circ}, \mathrm{T}_{\mathrm{r}}=-1,2\right)$. 
snímcích. Výsledky studia povrchových deformací na základě satelitních snímků ukazují, že skutečné epicentrum mohlo být pouze přibližně dva kilometry od pozemních objektů jaderné střelnice (Wang et al. 2018; Gaebler et al. 2019). Nejistota v určení epicentra exploze se tedy pohybuje řádově v jednotkách kilometrů, odchylka lokace vypočítané na ÚFZ v Brně od ostatních řešení je menší než pět kilometrů.

S ohledem na výše zmíněnou nejistotu v určení polohy epicentra je nutné počítat s možným systematickým posunem časů detekce oproti správné hodnotě (tedy hodnotě platné pro správnou polohu epicentra) až o 0,5 sekundy. Další systematický posun časů detekce může být způsoben chybou výpočtu přesného času exploze. Při interpretaci zjištěných časových reziduí $\mathrm{T}_{\mathrm{r}}$ je proto nutné brát ohled na poměrně vysokou možnou absolutní chybu. Nelze vyloučit systematický posun hodnot předpokládaných časů detekce (a tedy hodnot časových reziduí) i o vyšší desetiny sekundy, přestože výsledná časová rezidua ukazují, že pro středoevropské stanice tato chyba bude spíše menší.

Oproti tomu relativní chyba (tedy změna rozdílu času detekce mezi jednotlivými stanicemi) odvozená pro studovaný prostor střední Evropy (viz obr. 3) by při nejistotě v určení epicentra do 10 kilometrů neměla přesáhnout úroveň 0,1 sekundy, což je méně než chyba odpovídající nepřesnosti odečtu časů příchodů $P$ vln na většině stanic použitých v této studii. Lze tedy předpokládat, že velikost relativní chyby zjištěných časových reziduí nepřesáhla úroveň prvních desetin sekundy.

\section{Anomální hodnoty časových reziduí}

$\mathrm{V}$ rámci studia časových reziduí odečtů $\mathrm{P}$ vln ze severokorejské jaderné exploze z roku 2017 byla shromážděna data $z$ velkého množství stanic situovaných po celém světě. Časy detekce P vln byly pak na ÚFZ v Brně odečteny na cca 650 stanicích, mezi nimiž převažovaly stanice evropské (obr. 2). Celkem $205 \mathrm{z}$ těchto stanic je umístěných v obdélníku vymezujícím prostor diskutovaný $\mathrm{v}$ této práci, zaměřený na středoevropský region (obr. 3), pro zpracování hodnot v blízkosti okrajů tohoto obdélníku byla zohledněna rezidua na dalších 226 stanicích situovaných v okolí vymezeného prostoru. Výsledný obraz prostorového rozložení zjištěných časových reziduí $\mathrm{T}_{\mathrm{r}}$ pak ukazuje několik oblastí s anomálními hodnotami.

Vyšší kladné hodnoty časových reziduí $\mathrm{T}_{\mathrm{r}}$ (tedy zpoždění času detekce oproti modelovému předpokladu) byly zjištěny především $\mathrm{v}$ západní a severní části Západních Karpat, ve východní části Panonské pánve

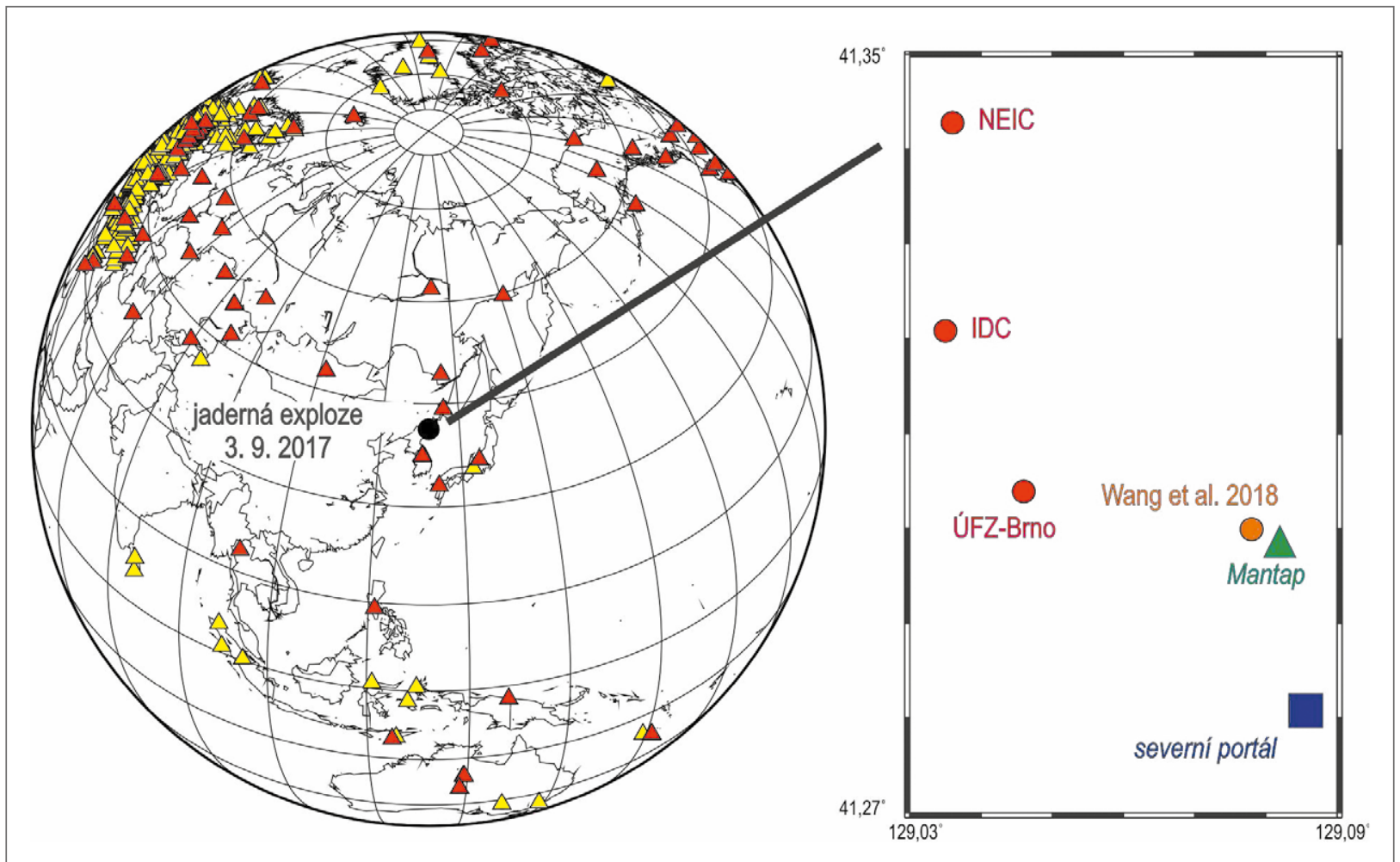

Obr. 2: Schematické mapy epicentra severokorejské jaderné exploze a umístění seismických stanic použitých v ÚFZ v Brně k lokaci exploze a ke studiu časových reziduí (vlevo - globální měřítko; vpravo - detailní výřez): červené trojúhelníky - stanice využité k lokaci jaderné exploze; žluté trojúhelníky - další stanice využité ke studiu časových reziduí; červená kolečka - epicentra exploze určená ze seismických dat; oranžové kolečko - epicentrum určené ze satelitních snímků (Wang et al. 2018); modrý čtverec - severní portál jaderné střelnice Pungyye-ri; zelený trojúhelník - vrchol hory Mantap.

Fig. 2: Schematic maps of epicentre of the North Korean nuclear explosion and position of seismic stations used by UFZ for location of nuclear explosion and for study of the time residuals (left map - global scale; right map - regional scale): red triangles - stations used for location; yellow triangles - stations used only for study of time residuals; red circles - epicentres of explosion calculated from seismic data; orange circle - epicentre detected using satellite imagery (Wang et al. 2018); blue square - north portal of test site Pungyye-ri; green triangle - peak of the Mantap Mt. 
a v regionu Transylvánské vysočiny. Naopak výrazně záporné hodnoty časových reziduí $\mathrm{T}_{\mathrm{r}}$ byly pozorovány v širokém prostoru Jižních vápencových Alp a východní části Pádské nížiny.

Největší zpoždění časů detekce seismických vln oproti modelovým předpokladům bylo pozorováno v západní části Západních Karpat, a to zejména na stanicích situovaných v místě s velkou mocností vnějších flyšových příkrovů (stanice JAVC u Velké Javořiny, tj. jižně od Uherského Brodu), popř́padě v jednotkách bradlového pásma (stanice NIE severně od Niedzice a vjv. od Noweho Targu), $\mathrm{v}$ jejichž př́padě dosahovalo zpoždění hodnot 1,2 až 1,3
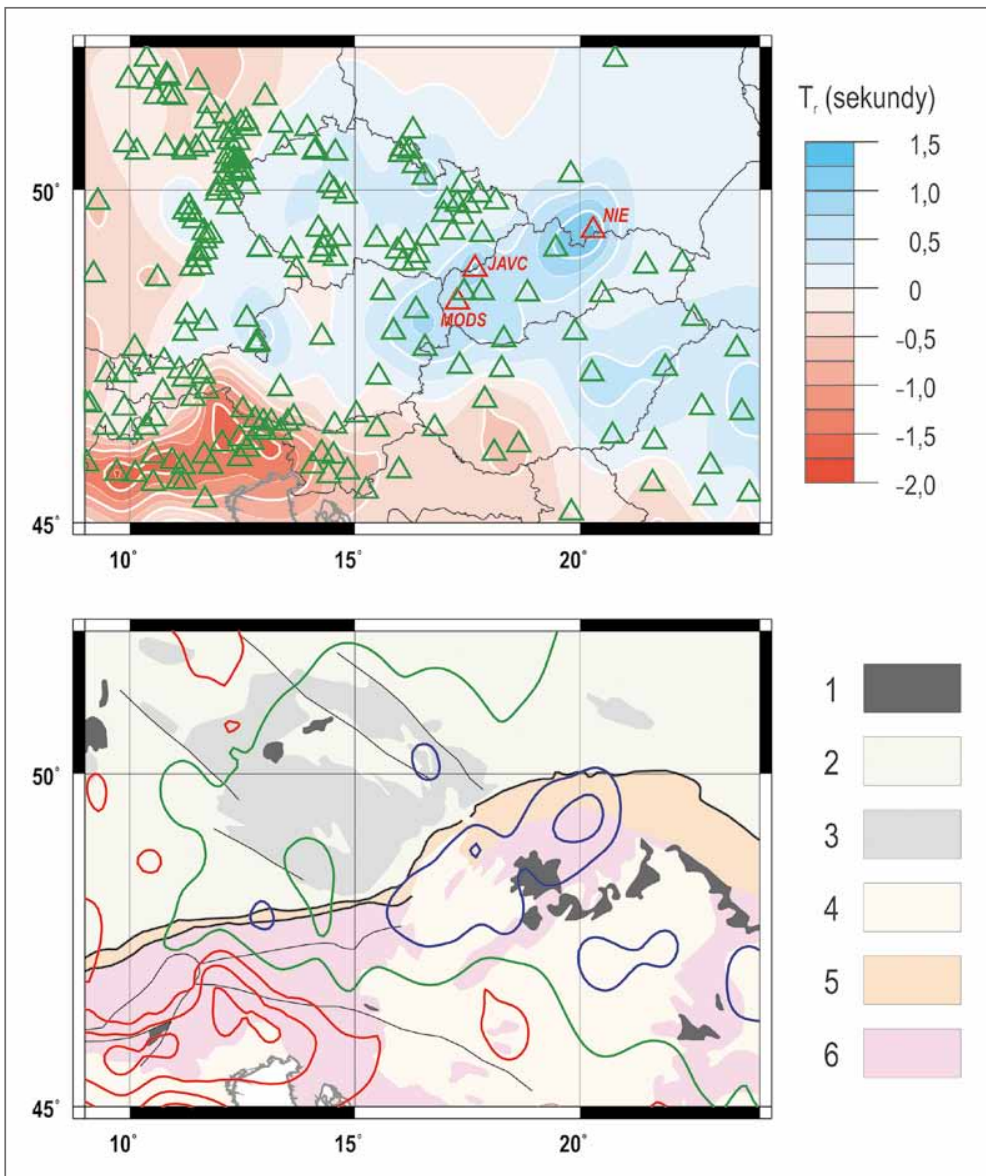

Obr. 3: Schematické mapy časových reziduí odečtů P vln ze severokorejské jaderné exploze z roku 2017. Nahoře: konturovaná mapa časových reziduí $\mathrm{T}_{\mathrm{r}}$, trojúhelníky vyznačují polohy využitých seismických stanic (červeně jsou vyznačeny stanice JAVC, MODS a NIE jmenované v textu, zeleně ostatní stanice). Dole: geologické schéma (podle Asche 2005, zjednodušeno) s vyznačenými konturami časových reziduí $\mathrm{T}_{\mathrm{r}}$ (červeně - izolinie záporných reziduí, modře - izolinie kladných reziduí, zeleně - izolinie $\mathrm{T}_{\mathrm{r}}=0$ ), legenda: 1 - kenozoické vulkanity; 2 - mesozoický a kenozoický pokryv alpinského předpolí; 3 - variský basement; 4 - neogenní pokryv alpinských jednotek; 5 - alpinský flyš; 6 - další alpinské jednotky.

Fig. 3: Schematic maps of P-wave arrival time residuals from the 2017 North Korean nuclear test. Upper map: Contoured map of time residuals $\mathrm{T}_{\mathrm{r}}$, triangles show positions of used seismic stations (red triangles - stations JAVC, MODS and NIE mentioned in text; green triangles - other stations). Lower map: geological scheme (after Asch 2005, simplified) with contours of the time residuals $\mathrm{T}_{\mathrm{r}}$, (red lines - negative residuals, blue - positive residuals, green $-\mathrm{T}_{\mathrm{r}}=0$ ), legend: 1 - Cenozoic volcanics; 2 - Mesozoic and Cenozoic cover of Alpine foreland; 3 - Variscan basement; 4 - Neogene cover of Alpine units; 5 - Alpine flysch; 6 - other Alpine units. sekundy. Přibližně sekundové zpoždění podélných vln na stanici JAVC provozované Ústavem fyziky Země bylo již od začátku jejího provozu (rok 1996) a bylo Seismické profily ukazují, že rychlost podélných vln dosahuje v těchto sedimentech pouze hodnot 3,8 až Kennoduché propocty Kahánkové (2012) ukázaly, že vliv zmíněných flyšových sedimentů na čas eismické vlny je významný, ovšem pro doložené mocnosti prŕkrovů pod stanicí tento vliv vysvětluje pozorované zpoždění pouze částečně. Jak ukazuje mapa reziduí v tomto článku, zpoždění (byt' ve srovnání se stanicemi JAVC a NIE znatelně menší) bylo pozorováno také na stanicích umístěných ve vnitřních jednotkách Západních Karpat (např. na stanicích MODS a SMOL situovaných v prostoru Malých Karpat dosáhla časová rezidua hodnoty 0,7 sekundy). Je tedy nutné předpokládat ještě další prričinu zpomalení seismických vln, kterou je nutné hledat ne hlouběji než v nejvyšších partiích zemského pláště, protože ovlivňuje také časy detekcí lomených vln Pn (viz časy zpoždění Pn vln na stanici JAVC publikované v práci Kahánkové 2012). Touto př́činou by mohlo být hlouběji položené a zvlněné MOHO rozhraní (viz Godová et al. 2018; Hrubcová et al. 2010), popřípadě přechodová zóna na rozhraní kůry a pláště, jejíž možná existence ale vyplývá pouze z některých seismických profilů (Hrubcová et al. 2008), zatímco jiné ji nepotvrzují (Hrubcová et al. 2010).

Region z. a s. části Západních Karpat, zejména prostor západokarpatského flyše, tedy reprezentuje příklad situace, kdy se vliv nehomogenity litosféry působící na seismický signál v různých hloubkových úrovních vzájemně zesiluje. Příklad opačné situace, kdy dochází k vzájemné eliminaci těchto vlivů, můžeme sledovat ve v. části Panonské pánve. Na jedné straně až více než $5 \mathrm{~km}$ mocné sedimenty způsobují zpoždění signálu, na druhé straně tenčí kůra, a tedy výše položené MOHO rozhraní, vede $\mathrm{k}$ rychlejšímu průchodu seismických vln (viz Janik et al. 2011; Koulakov et al. 2009; Ren et al. 2013). Ze sumarizovaných 1D modelů publikovaných $\mathrm{v}$ práci Janika et al. (2011) lze snadno odvodit, že vliv sedimentů na výsledný čas detekce by měl převažovat a i přes jeho oslabení rychlejšími partiemi v nejsvrchnější části pláště by měla být doba průchodu seismického paprsku nejsvrchnějšími $35 \mathrm{~km}$ litosféry 
v daném místě pomalejší o přibližně 0,4 až 0,6 sekundy (zpoždění $\mathrm{T}_{\mathrm{r}}$ pozorované pro signál severokorejské exploze na stanicích situovaných ve v. části Panonské pánve dosáhlo hodnoty až 0,7 sekundy).

Nečekané výsledky ukazuje vyhodnocení časových reziduí odečtů $\mathrm{P}$ vln severokorejské exploze $\mathrm{v}$ prostoru Východních Alp, kde nebyla pozorována výraznější kladná časová rezidua, s výjimkou okolí Salzburku a nejvýchodnějších částí Východních Alp v okolí Vídně, přestože seismické profily ukazují hlubší polohu MOHO rozhraní, popř́padě možnou existenci přechodové zóny na rozhraní kůry a pláště (Brückl et al. 2008; Cassinis 2006; Grad et al. 2009; Hrubcová et al. 2008), což jsou fenomény, které by měly způsobovat zpoždění časů detekce. Kladná časová rezidua v okolí Salzburku korespondují s nižšími rychlostmi příčných vln zjištěnými Behmem (2009) a mohou souviset s nižšími rychlostmi seismických vln v sedimentech alpinské molasy a flyše. I když seismické profily ukazují, že v regionu Východních Alp lze většinou očekávat jen malý vliv sedimentů alpinského flyše a molasy, na rozdíl od Západních Karpat, rychlosti seismických vln doložené ve spodní kůře refrakčními profily by měly způsobit zpoždění časů detekce podélných vln v prostoru Severních vápencových Alp o až 0,5 sekundy oproti Českému masivu. Časová rezidua podélných vln určená z detekcí signálu severokorejské jaderné exploze však taková zpoždění neukazují.

Příčina nepř́ítomnosti výraznějších kladných reziduí v regionu Východních Alp může souviset také $\mathrm{s}$ výrazně zápornými rezidui v prostoru severoitalských Alp. Seismické profily sice ukazují rychlejší horninové prostředí v prostoru j. od periadriatického lineamentu (tj. v korových jednotkách adriatické mikrodesky) ve srovnání s kůrou severnějších jednotek (Cassinis 2006; Grad et al. 2009), rychlosti seismických vln zjištěné v profilech ale nemohou vysvětlit předbíhání pozorovaných časů detekce seismických vln v prostoru Jižních vápencových
Alp jednu až dvě sekundy oproti severnějším jednotkám Východních Alp. Příčinu zrychlení seismických vln oproti modelovým předpokladům lze proto nejspíše hledat hlouběji ve svrchním plášti. Dosud známé výsledky seismické tomografie v prostoru Alp ukazují na existenci laterálních nehomogenit v zemském plášti (Amaru 2007; Karousová et al. 2013; Kind et al. 2017), jejichž vertikální rozměry jsou dostatečné $k$ tomu, aby se významněji projevily na výsledných časových reziduích odečtů seismických vln. Takové hypotetické zrychlení seismického signálu v plášti by mohlo postihnout i paprsky směřující do regionu Severních vápencových Alp a eliminovat tak zpomalující vliv mocnější kůry. Je ovšem nutné přiznat, že tato hypotéza je v této chvíli do značné míry spekulativní a je zde uvedena jen jako jedna z možností, jak vysvětlit pozorované hodnoty reziduí v daném regionu.

\section{Závěr}

Výše diskutované př́klady pozorovaných časových reziduí podélných vln ze severokorejské jaderné exploze ukazují, jak významně heterogenity v kůře a ve svrchním plášti ovlivňují časy detekovaných seismických vln. Pro regionální a globální seismické monitorování stanicemi situovanými ve střední Evropě (a především na území České republiky) je významným fenoménem především významné (až více než sekundové) zpoždění odečtů, oproti teoretickým odečtům plynoucím z modelu IASP91, v z. části Západních Karpat. Toto zpoždění je způsobeno souběžně nejen mocnými polohami flyšových sedimentů, ale další příčiny lze hledat ve spodní kůře a nejsvrchnějších partiích pláště.

\section{Poděkování}

Př́spèvek vznikl sinanční podporou projektu MŠMT, program č. LM2015079, CzechGeo/Epos. Autor děkuje obèma recenzentưm za jejich pripomínky. 


\section{Literatura}

Amaru, M. (2007). Global travel time tomography with 3-D reference models. - MS, PhD. Thesis. Faculty of Geosciences, Utrecht University.

Asch, K. (2005). The 1:5 Million International Geological Map of Europe and Adjacent Areas. - BGR. Hannover.

Behm, M. (2009). 3-D modelling of the crustal S-wave velocity structure from active source data: application to the Eastern Alps and the Bohemian Massif. - Geophysical Journal International, 179, 265-278. https://doi.org/10.1111/j.1365-246X.2009.04259.x

Behm, M., Brückl, E., Mitterbauer, U. (2007). A New Seismic Model of the Eastern Alps and its Relevance for Geodesy and Geodynamics. - VGI Österrreichische Zeitschrift für Vermessung \& Geoinformation, 2, 121-133.

Brückl, E., Bleibinhaus, F., Gosar, A., Grad M., Guterch, A., Hrubcová, P., Keller, G. R., Majdański, M., Šumanovac F., Tiira, T., Yliniemi, J., Hegedüs, E., Thybo, H. (2007). Crustal structure due to collisional and escape tectonics ine the Eastern Alps region based on profiles Alp01 add Alp02 from the ALP 2002 seismic experiment. - Journal of Geophysical Research, $112, \mathrm{~B} 06308$

Cassinis, R. (2006). Reviewing pre-TRANSALP DSS models. - Tectonophysics, 414, 79-86. https://doi.org/10.1016/j.tecto.2005.10.026

Gaebler, P., Ceranna, L., Nooshiri, N., Barth, A., Cesca, S., Frei M., Grünberg, I., Hartmann, G., Koch, K., Pilger, Ch., Ross, J. O., Dahm, T. (2019). A multi-technology analysis of the 2017 North Korean nuclear test. - Solid Earth, 10, 59-78. https://doi. org/10.5194/se-10-59-2019

Godová, D., Bielik, M., Šimonová, B. (2018). The deepest Moho in the Western Carpathians and its respective crustal density model (CEL12 section). - Contributions to Geophysics and Geodesy, 48, 3, 255-269. https://doi.org/10.2478/congeo-2018-0011

Grad, M., Guterch, A., Mazur, S., Keller, G. R., Špičák, A., Hrubcová, P., Geissler, W. H. (2008). Lithospheric structure of the Bohemian Massif and adjacent Variscan belt in central Europe based on profile S01 from the SUDETES 2003 experiment. - Journal of Geophysical Research, 113, B10304.

Grad, M., Brückl, E., Majdański, M., Behm, M., Guterch, A., CELEBRATION 2000 and ALP 2002 Working Groups (2009). Crustal structure of the Eastern Alps and their foreland: seismic model beneath the CEL10/Alp04 profile and tectonic implications. - Geophysical Journal International, 177, 279-295.

Hrubcová, P., Środa, P., CELEBRATION 2000 Working Group (2008): Crustal structure at the easternmost termination of the Variscan belt based on CELEBRATION 2000 and ALP 2002 data. - Tectonophysics, 460, 55-75.

Hrubcová, P., Środa, P., Grad, M., Geissler, W. H., Guterch, A., Vozár, J., Hegedüs, E., Sudetes 2003 Working Group (2010). From the Variscan to the Alpine Orogeny: crustal structure of the Bohemian Massif and the Western Carpathians in the light of the SUDETES 2003 seismic data. - Geophysical Journal International, 183, 611-633.

Janik, T., Grad, M., Guterch, A., Vozár, J., Bielik, M., Vozárová, A., Hegedüs, E., Kovács, C. A., Kovács, I., Keller, G. R., CELEBRATION 2000 Working Group (2011). Crustal structure of the Western Carpathians and Pannonian Basin: Seismic models from CELEBRATION 2000 data and geological implications. - Journal of Geodynamics, 52, 2, 97-113.

Kahánková, L. (2012). Ověření hypotetického vlivu rychlostní anomálie v podloží stanice JAVC (Velká Javorina) na časy př́íchodů seismických vln. - MS, bakalářská práce. Masarykova univerzita Brno.

Karousová, H., Plomerová, J., Babuška, V. (2013). Upper-mantle structure beneath the southern Bohemian Massif and its surroundings imaged by high-resolution tomography. - Geophysical Journal International, 194, 2, 1203-1215. https://doi. org/10.1093/gji/ggt159

Kennett, B. L. N. (1991). IASPEI 1991 Seismological Tables. - Researcher School of Earth Sciences, Australian National University.

Kind, R., Handy, M. R., Yuan, X., Meier, T., Kämpf, H., Soomro, R. (2017). Detection of a new sub-lithospheric discontinuity in Central Europe with S-receiver functions. - Tectonophysics, 700-701, 19-31.

Koulakov, I., Kaban, M. K., Tesauro, M., Cloetingh, S. (2009). P- and S-velocity anomalies in the upper mantle beneath Europe from tomographic inversion of ISC data. - Geophysical Journal International, 179, 345-366. https://doi.org/10.1111/j.1365-246X.2009.04279.x

Legendre, C. P., Meier, T., Lebedev, S., Friederich, W., Viereck-Götte, L. (2012). A shear wave velocity model of the European upper mantle from automated inversion of seismic shear and surface waveforms. - Geophysical Journal International, 191, 282-304. https://doi.org/10.1111/j.1365-246X.2012.05613.x

Ren, Y., Grecu, B., Stuart, G., Houseman, G., Hegedüs, E., South Carpathian Project Working Group (2013): Crustal structure of the Carpathian-Pannonian region from ambient noise tomography. - Geophysical Journal International, 195, 1351-1369.

Stráník, Z., Dvořák, J., Krejčí, O., Müller, P., Přichystal, A., Suk, M., Tomek, Č. (1993). The Contact of the North European Epivariscan Platform with the West Carpathians. - Journal of the Czech Geological Society, 38, 1-2, 21-29.

Wang, T., Shi, Q., Nikkhoo, M., Wei, S., Barbot, S., Dreger, D., Bürgmann, R., Motagh, M., Chen, Q. F. (2018). The rise, collapse, and compaction of Mt. Mantap from the 3 September 2017 North Korean nuclear test. - Science, 361(6398), 166-170. http://doi.org/10.1126/science.aar7230. 